\title{
Discursive framings of market-based education policy and their negotiation by students: the case of 'value for money' in English universities
}

\author{
Steven Jones ${ }^{\mathrm{a} *}$, Katy Vigurs ${ }^{\mathrm{b}}$ and Diane Harris ${ }^{\mathrm{c}}$ \\ ${ }^{a}$ Manchester Institute of Education, The University of Manchester, Oxford Road, Manchester, \\ M13 9PL, UK. ORCID: 0000-0002-4529-9996, @StevenJones_MCR \\ ${ }^{b}$ Centre for the Study of Practice \& Culture in Education (CSPACE), Birmingham City \\ University, Birmingham, B5 5JU, UK. ORCID:0000-0001-9535-5637, @drkatyvigurs \\ 'Manchester Institute of Education, The University of Manchester, Oxford Road, Manchester, \\ M13 9PL, UK. ORCID: 0000-0003-3600-7645.
}

*corresponding author: sj@ manchester.ac.uk, (+44) 1612753411

Word count: 7,449 (including footnotes) 


\title{
Discursive framings of market-based education policy and their negotiation by students: the case of 'value for money' in English universities
}

\begin{abstract}
Measures that economise education are typically accompanied by discourses that prime society for change by framing the policy in individualistic and consumeristic terms. This article explores the emergence of 'value for money' (VfM) discourses in the English higher education sector. Using Bourdieu's thinking tools, we explore how VfM is conceptualised by final year undergraduates paying different levels of 'headline' tuition fees at a Russell Group and a Post-92 university. Unsurprisingly, we find qualitative evidence of an increase in VfM negativity as fees rise. However, this does not distribute evenly across different groups of students. At both institutions, undergraduates approach VfM in complex and unexpected ways, drawing on different capitals and often pushing back against dominant discourses. A key finding is that many students report high levels of satisfaction with their institution, course and teaching, while simultaneously expressing VfM negativity because they feel tuition fees are too high.
\end{abstract}

Keywords: value for money; marketisation; tuition fees; student finance; student wellbeing.

Funding Details: This research was funded by the Society for Research into Higher Education (Greater Expectations of Post-Graduation Futures? A Comparative Analysis of the Views of the Last Generation of Lower-Fees Undergraduates with the First Generation of Higher-Fees Undergraduates at Two English Universities; PI: Katy Vigurs).

Disclosure statement: No potential conflict of interest was reported by the authors. 


\section{Introduction}

The market-based models of educational delivery and accountability that have become more widespread in recent decades (Ranson, 2003) are typically accompanied by discursive primings that seek to naturalise policy (Ball, 2017). Within higher education, 'value for money' (VfM) discourses offer an instructive example, typically positioning the student-consumer as exerciser of choice and evaluator of quality (Tomlinson, 2017), while repositioning the state as market regulator (Talbot, 2011). According to the logic of what Johnstone (2004) characterises as 'cost-sharing' discourses, individual learning is invigorated as students are empowered to drive change and raise standards within a more liberally regulated sector (Johnson, 2015; Willetts, 2011). Structural efficiency becomes entrenched as the burden of payment is transferred from taxpayers in general to those with the drive and agency to succeed (Hayek, 1973), and selfdetermination is maximised because student-consumers are making free and informed choices within a competitive market (Johnson, 2016 \& 2017). Furthermore, when self-interest is unleashed, historically rooted hierarchies are upset and 'spontaneous order' emerges (Hayek, 1945). However, subsuming societal advancement (Barnett, 1990) and public value creation (Moore, 1995) within individualised, economistic VfM narratives ${ }^{1}$ risks reducing higher education to an 'investment' in search of a 'return' (Brown \& Carasso, 2013) rather than a step toward a better informed, more civically engaged society (Nixon, 2010). Discourses that champion the student-consumer deflect from the personal indebtedness increasingly associated with university participation in England (McGettigan, 2013; Vigurs et al., 2018a) and the structural disempowerment of the sector as academic autonomies are conceded within a more centralised, metricised model (Smyth, 2017).

\footnotetext{
1 'Competition to recruit students leads providers to improve the experience they offer, often increasing value for money for students. The Office for Students oversees this competitive market and has a duty to promote value for money' (OfS, 2018a).
} 
In England's higher education landscape, so embedded is the language of VfM that it is difficult to imagine policy discourse without it. Despite being a dominant conceptual lens for mediating policy, VfM remains ill-defined and its assumptions largely uncontested. The fundamental question of whether VfM is something that can be 'delivered' by universities and 'ensured' by regulators is rarely addressed directly. ${ }^{2}$ More broadly, with discourses colonised by economistic rather than educational idiom (Collini, 2011, p. 9), publics are created (Bennington, 2009) that conceive the role of universities in policymakers' individualised terms rather than in relation to social returns (Public Accounts Committee, 2018).

This article reports on research from the 'Greater Expectations of Graduate Futures?' project (Vigurs et al., 2016) to explore the extent to which VfM's ubiquity in public discourse is consistent with the meaning and significance attached to it by students. The research offers two theoretical contributions. First, with the notion of 'public value' - broadly defined as an organisation's contribution to society (Moore, 1995) - now less present in higher education policy, we consider the extent to which more consumeristic framings, and the ideologies they seek to normalise, are internalised or eschewed by students. Second, drawing on a Bourdieusian theorisation of the exchange of 'capitals' in the higher education field (Naidoo, 2004), we gauge the extent to which students' conceptualisation of value is influenced by their background characteristics. Previous research has drawn upon Bourdieu's work to demonstrate how habitus is revealed through students' engagement with university, and show that different groups bring different capitals to the higher education field (Reay et al., 2005). However, the rapid move to a market-based system in England changes the 'rules of the game' (Bourdieu, 2000). In making our contributions, we follow Benington's (2009) view that 'publics' do not

\footnotetext{
${ }^{2}$ Where VfM is used in object position in Fulfilling Our Potential (Johnson, 2015), 'delivered' and 'ensured' are the two transitive verbs that precede it most commonly. Others include 'drive', 'champion', 'demand' and 'get'. The implication is that VfM is a known, measurable and attainable quality.
} 
develop naturally; they are created. We therefore unpick the kind of publics that VfM discourses project, specifically testing assumptions that position students as a homogenous grouping and VfM as a single ontological truth. By moving beyond students' binary assessments of VfM, we allow a richer and more in-depth picture to develop. In policy terms, a significant feature of this research is its analysis of whether students' perceptions of VfM are shaped more by the perceived quality of their (educational) provision, as the discourse insists, or by the (financial) cost of their participation.

\section{The emergence of 'value for money' discourses in higher education}

The pervasiveness of VfM rhetoric in higher education is a relatively recent phenomenon. The phrase is not used at all in the Robbins Report (1963), and only two of its 26 mentions in the Dearing Report (1997) relate to students. However, though infrequent, those allusions do foretell the arrival of a new discourse.

'We envisage that over time, some substantial part of the funding for tuition ... should transfer from the Funding Bodies to students, in the form of vouchers or proxy fees. This would encourage the student to see him/herself as an investor in receipt of a service, and to seek, as an investor, value for money and a good return from the investment.'

Dearing, 1997, p. 22.19

Although the statement above marks the beginning of explicitly market-based language in higher education policy, references to VfM remain rare for over a decade until the appointment of David Willetts as Minister of State for Universities and Science in 2010. Speaking in Parliament about proposals to increase competition in the UK market, he notes that new providers would 'ensure value for money and real choice for learners' (Willetts, 2011). The 
link with 'choice' is formalised by the publication of Students at the Heart of the System (Department for Business, Innovation and Skills, 2011), where VfM is referenced no fewer than 18 times, almost half of which relate to students. ${ }^{3}$ In Fulfilling Our Potential (Johnson, 2015), the total number of VfM mentions rises to 47 , with a similar proportion relating to students. Here, VfM is used overtly to justify market measures, as 'more choice between providers means that students can demand better value for money for their tuition fees' (2015, 13), and to promote institutional accountability, 'ensuring the rights of students to hold providers to account and get value for money for their investment' $(2015$, p. 62).

Typically, contemporary public discourses of higher education frame studentconsumers as recipients of poor VfM and therefore in need of statutory protection. Evidence normally draws on one of two sources. The first is the Student Academic Experience Survey, undertaken jointly by the Higher Education Policy Institute and the Higher Education Academy, the 2018 version of which found that $32 \%$ of students judge their courses to represent 'poor' or 'very poor' VfM (Neves \& Hillman, 2018). The second is a one-off consumer magazine report called 'A Degree of Value,' which found that $32 \%$ of students do not associate their degree with good VfM (Which?, 2014). ${ }^{4}$

It is useful to consider the fuller context of both sources. For example, when Student Academic Experience Surveys ${ }^{5}$ are cited, the proportion of students reporting poor VfM is typically interpreted by policymakers as evidence of low teaching quality. ${ }^{6}$ However, it should

\footnotetext{
${ }^{3}$ References to VfM in Students at the Heart of the System (Department for Business, Innovation and Skills, 2011) include 'we expect new courses to offer increased value for money, as they will be delivered by a range of providers with different business models' (2011, p. 7) and 'institutions that can attract students, by showing them that they offer good quality and good value for money, should grow and prosper, and may well increase their overall income' (2011, p. 15).

${ }^{4}$ Both sources are cited directly in the 2016 government White Paper Success as a Knowledge Economy (Johnson, 2016).

${ }^{5}$ The survey's sample size (14,057 in $2017 ; 14,046$ in 2018$)$ represents under $2 \%$ of the undergraduate population in England.

${ }^{6}$ For example, 'for a second year, the Higher Education Policy Institute Student Survey has shown more students in England (37\%) believing they have received poor value than good value
} 
be noted that for Scottish students studying in Scottish universities, where tuition is free, the perception of VfM is more favourable (60\% VfM positive in 2018 , compared to $35 \%$ in England). ${ }^{7}$ It is also noteworthy that perceptions of VfM differ markedly according to subject, with those on Medicine and Dentistry programmes 62\% VfM positive and those on Business and Administrative Studies programmes only 28\% VfM positive (Neves and Hillman, 2018). In similar research, the Office for Students (OfS 2018b) note variation in VfM positivity ranging from 53\% (Computer Sciences) to 26\% (Historical and Philosophical Studies). One might therefore infer that students' perceptions of VfM reveal more about fee levels and anticipated graduate income than about teaching quality. In 2016, this was acknowledged by the authors of the Student Academic Experience Survey, who attributed the decrease in VfM positivity to students 'incurring much larger debts than in the past even though universities' teaching income has not increased commensurately' (Neves \& Hillman, 2016, p. 14). The following year's report explicitly stated that VfM negativity 'does not signify a decline in [teaching] quality' (Neves \& Hillman, 2017, p. 7), noting a year-on-year rise in positive responses to all eight relevant questions (Neves \& Hillman, 2017, p. 37). When reported in public discourses, such details are often overlooked.

The second source of evidence typically cited, the 2014 Which? report, is imprecise in its methodology, ${ }^{8}$ conflating findings from different data gathering processes conducted at different times that draw on different methods. Closer examination once again suggests that

(32\%)... Students taking out taxpayer-backed loans to attend university rightly expect the highest quality teaching and to secure good labour market outcomes that justify their investment of time and money' (Johnson, 2017).

${ }^{7}$ Similar findings are reported by the OfS: ' $70 \%$ of those studying in Scotland agree that [university] has been good value for money, compared to just over half (54\%) of those in England' (2018b, p. 9). ${ }^{8}$ Within the hotchpotch of data amassed for the Which? study were 'qualitative focus groups and surveys to explore perceptions of value for money; diary research and analysis of the Higher Education Policy Institute / Higher Education Academy 2014 Student Academic Experience Survey to consider the academic offer; and secondary research of the literature to consider the objective evidence' $(2014$, p. 8$)$. 
students may have been responding more to the abruptness of the 2012 rise in tuition fees than to any perceived fall in teaching quality: VfM positivity was reportedly $81 \%$ for students entering university before 2012 and 68\% for those entering afterwards (Which?, 2014). In other words, even based on the sources cited by policymakers, there is a strong indication that that negative perceptions of VfM are driven by rising costs, with students perhaps assuming that a near-tripling in fees would have enriched universities sufficiently to trigger an upgraded provision.

However, despite question marks against parts of the evidence base, VfM public discourses remain rife. ${ }^{9}$ To give one example, speaking at an event hosted by think-tank Reform on 20th July 2017, the then Minister for University and Science, Jo Johnson, began by claiming that 'when students and taxpayers invest so heavily in our higher education system, value for money should be guaranteed.' He then outlined three steps being taken to 'ensure we deliver value for money,' appropriating the discourse to validate a number of disparate regulatory measures. The first step involved making it easier for new providers to enter the higher education market, a VfM issue because accelerated degrees allow students to borrow less money over a shorter period and therefore forgo less in terms of missed earnings. The second step involved the implementation of a subject-level Teaching Excellence Framework, a VfM issue because it would be 'an even more powerful driver of quality and value'. And the third step involved establishing the OfS, a VfM issue because 'Parliament has granted a general duty to promote value for money in higher education'. These three steps all demonstrate how the notion of VfM is assumed to resonate positively in public discourse. The speech closed with

\footnotetext{
${ }^{9}$ VfM discourses continued to abound following the appointment of Sam Gyimah as Minister of State for Universities, Science, Research and Innovation in 2018. Though stating 'I do not see the value of a university education solely hanging on its contribution to one's lifetime earnings,' he nonetheless reminds universities of the need to 'focus relentlessly on value for money' (Gyimah, 2018).
} 
the promise to develop 'a contract that underpins [students'] rights as consumers, and ensures value for money throughout their course and during their working lives.'

McCowan (2017) critiques the trend towards personalisation and employability that accompanied the fee rise, noting that the 'unbundling' of university provisions does not always impact positively on students. Within the research literatures, the underlying notion of 'student as customer' is problematised in multiple ways (Budd, 2017; Raaper, 2017; Tomlinson, 2017). In their investigation of how the financial benefits of university participation are perceived, Cook, Watson, and Webb (2018) acknowledge that 'as a degree becomes increasingly seen through a consumerist lens, value for money will become paramount,' and students now appear to place greater emphasis than ever before on employability (Bates \& Kaye, 2014). Some commentators have argued that this leads to increased disquiet among the undergraduate population (Wilkins, Shams \& Huisman, 2013), with Bachan (2014) reporting that levels of anxiety are strongly influenced by students' gender, ethnicity and year of study. Woodall, Hiller, and Resnick conclude that value is a 'slippery concept' (2014, p. 48), difficult both to conceptualise and to measure, and that its drivers vary between different types of student. Despite this, public reports continue to draw primarily on administrative datasets of graduates' career earnings to measure the impact of higher education (e.g. Institute for Fiscal Studies, 2004).

In 2018, a new sector regulator, the Office for Students (OfS), was established with the explicit remit to 'promote value for money in the provision of higher education' (Higher Education and Research Act, 2017). However, as noted by the Public Accounts Committee, 'neither the OfS nor the Department has articulated well enough what value for money means in higher education, or how they will seek to monitor and improve it' (2018, p. 5). ${ }^{10}$ A technical

\footnotetext{
${ }^{10}$ We do not discuss the National Student Survey in this article because, although the most official barometer of student satisfaction at UK universities, it includes no direct measure of VfM.
} 
reason why students at English universities are poorly positioned to assess VfM is that the final cost of participation remains unknown to them for up to thirty years after graduation because of the salary-dependent nature of repayments. However, the reliance on students' binary assessment of VfM in policy discourse and sector regulation raises more basic questions, which we now address:

- Do university students see education through a VfM lens?

- Do students from different backgrounds apply different criteria when assessing VfM?

- Does the type ${ }^{11}$ of university attended affect students' perceptions of VfM?

In response, we present evidence from a project that involved in-depth interviews with 92 graduands (university students who are about to graduate) at two English universities, one a Russell Group (RG) and one a Post-92 institution. ${ }^{12}$ In one-to-one interviews, participants were encouraged to reflect on issues around their student debt, their impending transition into the job market or postgraduate study, and their perceptions of VfM.

\section{Context, Data, Methods}

Though it is claimed that pessimistic predictions about the tuition fee increase have proved unfounded (Hillman, 2016), we find that a closer and more nuanced look at students' responses to higher fees tells a different story. By conducting detailed interviews with graduands, rather than impersonal surveys and personality tests, we aimed to uncover the shifting ways in which students engage with higher education as the financial costs of participation rise. Using graduands as interviewees also allows for perceptions of VfM to be gauged most dependably,

\footnotetext{
${ }^{11}$ This question is explored in part because Student Academic Experience Surveys (e.g. Neves \& Hillman, 2018) find VfM positivity to be greater among students at RG universities (42\%) than among those at Post-92 universities (35\%). Similar differences are noted elsewhere (OfS, 2018b). ${ }^{12}$ The RG is a self-selecting group of 24 research-focused universities in the UK. Post-92 universities, also known as 'new' universities, are former polytechnics awarded university status in or since 1992. The RG is usually associated with higher prestige.
} 
because the university experience remains sufficiently recent for its quality to be meaningfully assessed without the student's next steps being too distant to anticipate.

In 2012, as part of what McGettigan characterises as a 'new wave of public sector privatisation' (2013, p. 9), tuition fees of up to $£ 9,000$ per year were introduced for undergraduates at English universities (Department for Business, Innovation and Skills, 2011). Repayments continued to be deferred, beginning only when a predetermined salary threshold was reached (£21,000 per annum when this research was conducted). Our project aimed to conduct semi-structured interviews with 50 final year undergraduate students ( 25 from a RG university and 25 from a Post-92 university) in 2014 , when fees of $£ 3,350$ per year were being charged, and a matching ${ }^{13}$ group of 50 students in 2015 , when fees of up to $£ 9,000$ per year were being charged. All of those approached were under 25 years old and from one of three educational backgrounds: (1) attended a fee-paying independent school; (2) attended a state school without qualifying for institutional WP-related bursary funding (non-WP); (3) attended state school and qualified for institutional WP-related bursary funding for at least two years of their programme (WP). ${ }^{14}$ In total, we were able to interview 92 students, 48 of whom studied at a RG university and 44 of whom studied at a Post-92 university. Of those students, 44 were in the lower-fees cohort (24 RG; 20 Post-92) and 48 were in the higher-fees cohort (24 RG; 24 Post-92).

\footnotetext{
${ }^{13}$ In the higher-fees cohort, as far as possible, students were 'matched' with those from the previous year's lower-fees cohort. This means that we sought to identify participants who were comparable in terms of socio-economic background, gender, degree subjects and secondary school type. Where an exact match for programme of study was not possible, we matched more broadly at the level of discipline type. Perfect matches were contacted first and it was not until those students had indicated that they did not wish to be involved (or had failed to reply to the third e-mail invitation) that second choice matches were contacted. All but 18 of the 92 participants were successfully matched. In this way, comparability was maximised (see Vigurs et al., 2018a).

${ }^{14}$ WP stands for Widening Participation. The term is used to characterise under-represented groups, such as those from lower income families. Our definition of WP follows those of the two universities at which the research project was undertaken. A fuller discussion is offered in Vigurs et al. (2018a).
} 
Full ethical approval was given by both universities. Participants were provided with an information sheet in advance that outlined the purpose of the research and confirmed that they could withdraw at any time without explanation. Care was taken to disguise discipline areas so that individuals and their institutions remain anonymous. All interviews were conducted by the same researcher - face-to-face, by Skype or by telephone, in accordance with the student's preference - and a voucher was later issued as a 'thank you' to those who participated.

\section{Findings and Analysis}

We begin this section by outlining broader patterns among respondents before moving towards a more nuanced interpretation of how VfM is conceptualised. When asked directly whether they felt their degree programme had represented good VfM, the majority took the opportunity to reflect on both positive and negative elements of their experience before giving an answer. In total, $45 \%$ were ultimately VfM positive and 35\% VfM negative, a split broadly consistent with that found in larger studies (Neves \& Hillman, 2016, 2017 and 2018; National Audit Office, 2017). The remaining fifth of interviewees were unable or unwilling to offer a clear response, most often because they did not feel able to assess VfM in relation to an educational experience that they were still undertaking (albeit that they were towards the end of their programme of study). Exchanges like the one below, in which the VfM question is never directly answered, were common:

Interviewer: Has your degree represented good value for money?

Student (2014, RG, Mathematics, state school, non-WP): It depends. Obviously I think the whole point of a degree is that it's more about self-learning and about how 
you approach things ... this year I've utilized lecturers' free time a lot more and got a lot more out of it.

Interviewer: Okay, so you reckon your third year has been good value for money?

Student: I've really enjoyed third year. I think I chose good modules and I've put more work in. I can't say I'll reap the rewards of putting more work in but I've enjoyed it a lot more.

Here, the student remains equivocal, even when pressed. Like many of her peers, she finds it more natural to frame her time at university through a non-VfM lens, in this case by talking about the changing ways in which she engages with her studies. She does not know the extent to which longer term rewards might be reaped. Other interviewees similarly emphasised that it was too early for them to gauge VfM in an accurate or meaningful fashion:

- 2015, Post-92, Screenwriting, state school, WP: You don't really know about money before you go to university so when I applied for the course it was just 'oh I'm going off to university' and not really looking at fees because you don't think about the cost.

- 2015, Post-92, English and Creative Writing, state school, non-WP: In the long term, in ten years' time, if I'm earning like a lot of money because of the degree, then I'll look back and think it was worth every penny.

- 2014, RG, Biology, state school, WP: I'm not really paying for it now. I've not really thought about it that much. I don't know how much it is in tuition fees. Three? Nine? Well I've not spent that much on myself for anything [else]. I don't know what life will be like.

The first response above echoes some students' 'denial' about their finances, as reported by Harrison et al. (2015), while the second and third capture the difficulty students face in 
foreseeing their life-course and of benchmarking their educational 'purchase' against any comparable investment. Of those interviewees who did arrive at a clear answer, the proportion of VfM positive was $10 \%$ higher among the lower-fees cohort than the higher-fees cohort. ${ }^{15}$

\section{VfM positive students}

We begin by considering those students we characterise as VfM positive based on their response to the direct question and to their statements elsewhere in the interview. Many VfM positive students had internalised public discourses that frame university participation in more individual, instrumental terms and were content with the estimated return on their investment. Their choice of subject was often determined by rational economic thinking. Although we found state educated students, both WP and non-WP, expressing satisfaction, VfM positive students were disproportionately likely to be schooled in the independent sector:

- 2015, RG, History, independent school, non-WP: I'm lucky enough that my parents are paying the fees for me. I went to a boarding school and that cost $£ 30 \mathrm{k}$ a year so $£ 9 k$ a year doesn't seem very much.

- 2015, Post-92, Automotive Engineering, independent school, non-WP: My university right now is being funded by my parents so I'm not taking out a loan or anything so it's not affecting me or them much. I am concerned about my future and finding a job and being paid what I deserve.

The statements above echo the rhetoric of recent higher education policy. Students from independent school backgrounds are well placed to compare their perception of VfM at university with that of previous educational investments, often finding that it represents

\footnotetext{
${ }^{15}$ Though numbers are small, this fall was sharper among students at the Post-92 university than at the RG university, and among state educated students who did not qualify for bursaries than among state educated students who did qualify for bursaries.
} 
superior VfM to a fee-paying school. A sense of entitlement often arises ('being paid what I deserve'), as does an awareness of the non-academic capitals that can be accrued at university, as the following exchange demonstrates:

- 2014, Post-92, Drama and Theatre Studies, independent school, non-WP: (have you been doing part-time jobs?) I haven't, no. My parents are very good in that they felt that uni should just be for uni and so they've always said that they would support me to not have to get a job so that I could just go full pelt into my studies and I've done that. In this way I've been able to do other plays, choirs, all that kind of thing which I just wouldn't have been able to do really if I'd had to have a job. I feel I wouldn't mind paying whatever the fee if I could have that experience. I've got some contacts now and I feel I'm ready to take the next step and I'd far rather be in this position with a lot of debt than, you know, having gone to, I don't know, done another route and not be as socially confident.

The student above references both cultural capital ('plays, choirs, all that kind of thing') and social capital ('I've got some contacts now'), preferring to be 'in this position, with a lot of debt' rather than to have 'done another route and not be as socially confident'. Though VfM positive, she betrays an unusually privileged position: it is only because of parental financial support that the student is able to avoid part-time employment and instead cultivate the nonacademic capitals felt to be of greater value. This contrasts with VfM positive state educated students, for whom a more instrumental approach to participation was articulated, with the purpose of a university education more likely to be seen in terms of enhanced employability and earnings potential. For those at the RG universities in particular, perceptions of VfM tended to arise through cost-benefit analyses, with an undergraduate degree emerging as a prudent 
outlay. An awareness of the rising proportion of the population holding a degree-level qualification was common, and higher education was typically framed as the new 'normal' level of qualification.

- 2015, RG, Physics, state school, non-WP: Career-wise it's probably the investment you need to make.

- 2014, RG, Accounting, state school, WP: (Do financial issues play a part in your decisions about what to do next, such as pursuing postgraduate study)? Yes they do. Yes they one hundred per cent do. Like, I'm not particularly from an affluent background so therefore I am very mindful that when I finish university I have to be very self-sufficient in order to continue paying off my debts. So one of the main reasons why I'm going into the career I am, even though I'm not particularly romanticised by the accounting career, it is because there is good prospects, good economic prospects by joining that career.

The second statement above reflects the way in which assessments of VfM connect with WP students' anticipated graduate transitions, especially in relation to the avoidance of what Formby (2017) characterises as the 'stigma' of precarious employment. Despite being 'not particularly romanticised' by accounting, the student regards self-reliance and long term economic sufficiency as more important than educational enlightenment or personal fulfilment. State educated VfM positive students were more likely to be influenced by perceived graduate labour opportunities when selecting their degree programme. This was particularly pronounced among those in the lower-fees cohort, many of whom reflected on how their choice of subject would have been different had they entered university one year later. 
- 2014, RG, Philosophy and Politics, state school, WP: I don't think I would've come to university with the nine grand, and if I would have it would have been something vocational I think.

- 2014, RG, Politics and Modern History, state school, WP: My mates laugh because if you're doing an arts course, you're paying for like an extended library card really. That's all you're getting. If you're doing a science degree, you get so much equipment and chemicals and stuff which is worth thousands of pounds spent on each student per year on the stuff they use. You know what I mean? It's not really good value for money but there's nothing you can do about it.

- 2014, Post-92, Photography, state school, non-WP: Yeah I think it was three and a half [thousand pounds for me] and then the next year it went up. I don't think I'd have done my course that I did do. I'd have done something a lot more academic I think if I did go. I don't think I'd have done photography, no way.

For students such as those above, an association is readily volunteered between VfM and subject choice. Arts disciplines are parodied as an 'extended library card' and cross-subsidy implied to be inevitable. The final statement, in which the subject of photography is framed as an unsuitable choice in the higher fees era, reflects the extent to which state educated students are second guessing the requirements of the labour market.

\section{VfM negative students}

We now turn to those students that we characterise as VfM negative. For some, this negativity was driven by financial anxiety about their future. ${ }^{16}$ However, many interviewees had

\footnotetext{
${ }^{16}$ Comments such as 'there's a lot to pay back - it is a lot of money' (2015, RG, Healthcare Science, state school, non-WP) and 'I' $m$ in the deepest pit imaginable' (2015, Post-92, Journalism, state school, WP) were familiar.
} 
experienced acute hardship during their degree. The two statements below, supplied by higherfees graduands attending different universities, are similar in that they describe a shortfall in income that resulted in them being unable to meet basic living expenses.

- 2015, RG, Mathematics and Actuarial Science, state school, non-WP: When I came to university, I was expecting that the loan that you were given was enough, but it really isn't. Like all I get is the maintenance loan which I think is $£ 3 \mathrm{k}$ and I spent $£ 4 k$ so I didn't realize that I literally wouldn't be able to afford it and I've had to ask my parents for money.

- 2015, Post-92, Geography, state school, non-WP: If you get the minimum amount it doesn't even cover your rent. I mean it's very cheap where we live at the moment and my loan does cover that but I have to get the food from somewhere else. Where are you going to get that money from?

VfM negativity was therefore driven by day-to-day economic pressures more than by rounded reflections on the long term impact of participation. Perceived injustice across time often aggravated negativity, with students in both cohorts remarking on the rapidity of the increase of the fees and drawing comparisons with siblings who participated under a different funding system. This often acted as a catalyst for annoyance, given the prospect of members of the same family repaying different levels of debt for different periods of time on different terms.

- 2015, RG, Mathematics and Actuarial Science, state school, non-WP: I've got an older brother who got an entire degree for the price of one of my years.

- 2015, Post-92, English, state school, non-WP: My sister went ten years ago as well so she paid like the $£ 3 \mathrm{k}$ and I can’t see that anything has substantially changed from how her course was and how my course is now. So I don't think it was worth the money. 
- 2014, RG, Criminology, state school, WP: I mean my brother's in university and he's paying nine grand a year and he's like 'why?'

Discontent was generally triggered by localised disparities,${ }^{17}$ with teaching-related issues cited as the reason for VfM negatively by a relatively small proportion of interviewees only. Though the criticisms below are damning, it is noticeable that their focus is not on teaching quality in isolation but rather in relation to cost.

- 2015, Post-92, Photojournalism, state school, WP: I found that throughout the degree I've not really learnt anything that I didn't know before so that's why my barriers are up to it, because I went 'well this is all well and good but I'm paying $£ 9 \mathrm{k}$ a year for something where I'm not learning anything'.

- 2015, Post-92, Computer Games Design, state school, WP : After going through the three years and seeing how badly taught some of the content was and how half-hearted some of the lecturers were, I felt like $£ 9 k$ was the biggest waste of money for every year that I've paid. I'd say if they're going to start changing that then the universities need to buck their ideas up and actually teach $£ 9 k$ worth of content.

Negativity towards teaching quality concentrated around the higher-fees cohort at the Post-92 university, as the statements above suggest. Frustration that additional costs had not resulted in improved teaching quality was voiced, with disappointment compounded by a sense that the 'signalling' value of their degree may be lesser than that of those awarded by other institutions (Callender \& Jackson, 2008). However, a number of students made statements that pointed towards a disconnect between the perceived (positive) quality of their experience and their

\footnotetext{
${ }^{17}$ One interviewee noted that 'it is annoying to hear that in, like, Scotland it's free' (2015, Post-92, Film, TV and Radio Studies, state school, WP).
} 
perceived (negative) VfM. For example, the student below is effusive about the quality of his institution, course and teaching but ultimately VfM negative:

- 2015, Post-92, Law, state school, WP: (Has your degree represented good 'value for money'?) Yes and no. The lecturers and tutors at the university are great. They're really supportive and you can email them or chat to them. They'll help you out the best they can. They're always there to help you out academically and personally. The course has been great and the university has been good. The $£ 9 k$, I mean I don't know why they put it up to that because it should really still be free. $£ 3 \mathrm{k}$ a year is quite a lot. Even that's questionable that that's good value, that's reasonable. $£ 9 k$ isn't good value. I don't think it's that good value for me, $£ 27 \mathrm{k}$ when before it was $£ 9 k$ for the whole lot so, yeah.

The statement above carries significance in policy terms, evidence that the link readily assumed between VfM and teaching quality (Johnson, 2017; Higher Education and Research Bill, 2017; OfS, 2018b) may be based on false premises. To conflate the two is to overlook the substantial influence of cost on students' assessment of VfM. Indeed, the 2018 Student Academic Experience Survey acknowledged this by carrying a new question asking what students are predominantly thinking when they assess VfM. The most common explanation offered for VfM negativity, at 62\%, was tuition fees (Neves \& Hillman, 2018).

\section{Discussion}

In England, while it is government policy that has turned undergraduates into consumers, it is the associated discourses that have legitimated the funding model, normalised the market, and coaxed students towards thinking in more commercial ways. However, the evidence we present here suggests that consumerism is far from the default disposition of students. Interviewees frequently reported being inadequately placed to judge VfM. This was partly because our sampling point did not allow for longer term VfM reflections on the financial impact of 
participation. However, it was also because many students struggled to visualise their future with clarity, and therefore either rejected the VfM lens outright or sought proxies such as contact hours to make sense of the question asked. Where the VfM lens was accepted, and the language of VfM deployed, students generally fell into one of two groups. The first group disproportionately comprised those who had attended a fee-paying school were able to compare their higher education 'deal' to that received previously. Such students tended to use their time at university to accrue non-academic capitals, unencumbered by short term economic anxieties. The second group disproportionately comprised students who were state educated, particularly those not in receipt of a bursary. Such students tended to report higher levels of VfM negativity and often faced severe short term financial worries. VfM discourses were here mobilised in a very different way - to allocate blame and to hold the institution to account. ${ }^{18}$ Criticism of teaching quality was largely confined to this group. In between these two extremes lay a majority of students for whom participation was perceived as a prerequisite for entry to a particular labour market, and VfM therefore regarded as an incongruous, perplexing framing.

That monetary factors constrain students' engagement with higher education is well documented in the literature (McGuigan et al., 2016; Callender \& Mason, 2017). It is also accepted that state school students, particularly those from a WP background, conceptualise higher education differently from other students (Jones, 2016; Reay et al., 2010). Though changes to the campus environment were acknowledged following the 2012 increase in tuition fees (Jones et al., 2016), few improvements in teaching quality were reported. Many VfM negative students complained that the fee levels they faced were greater or lesser than that of a sibling, even though the perceived quality of the degree was no different. Structurally, therefore, our results align with warnings issued about the 'points of failure' in the higher

\footnotetext{
${ }^{18}$ One interviewee had even calculated the 'cost' of her individual lectures by dividing her annual tuition fees by the number of contact hours received.
} 
education market (National Audit Office, 2017), namely that despite the language of empowerment embedded within policymakers' rhetoric, students can do little to influence the quality of their degree programme once they are enrolled.

By interviewing graduands at different types of institution, we were able to assess the extent to which conceptualisations of VfM varied across the English sector. Findings here were not clear cut, but our evidence indicates that, as fees rise, Post-92 universities face a greater challenge to justify their worth than RG universities. For students at the Post-92 university, VfM negativity was particularly evident in the higher-fees cohort. Awareness seemed to be growing that, regardless of how much they resisted the metaphor, the 'product' that they were being sold may not have comparable exchange value in the graduate employment market (Harris et al., 2015). Our findings are broadly reflective of Temple et al.'s (2014) conclusion that higher fees are not an issue of over-riding significance for RG universities, where the 2012 increase in fee levels was more likely to be taken in students' stride. Similarly, students' choice of degree course at the Post-92 university was driven more by perceived employability than those at the RG university. Over one third of those in the lower-fees cohort indicated that they would have chosen a more vocational course had they been paying higher fees. Despite this, like Tomlinson (2017), we found evidence of some resistance to dominant, market instrumentalist narratives of higher education. Though financial apprehension levels were almost universally high among the state educated students that we interviewed, creative ways were often found to talk about indebtedness. For example, the 'gap year' was re-imagined as the period followed graduation in which to consolidate and repay urgent debt, and the parental home, where possible, was framed as temporary sanctuary (Vigurs et al., 2018b).

The tendency for WP students in receipt of a bursary to be more VfM positive requires further investigation. As Harrison and McCaig (2017) note, the relationship between financial support and educational disadvantage is not well understood. On the surface, and based on 
rational economic assumptions, non-repayable financial assistance should increase VfM positivity because it reduces the overall cost of participation. However, our findings point to a more profound effect because of the message of support that bursaries send: students felt that non-repayable financial support, in recognition of previous disadvantage, carried symbolic weight in terms of institutional belonging. This was particularly notable among eligible students at the RG university, the only sub-group for whom VfM positivity increased following the fee increase.

\section{Conclusion}

In this article we have shown that, despite it discursive centrality, VfM is not a lens through which students naturally or spontaneously view their time at university. This exposes a conflict between how policymakers position students - as economically rational, symmetrically informed and similarly predisposed agents operating in a transparent field - and how students see themselves. No one ever favours not getting VfM, as Collini (2016) notes. However, the insistent focus on VfM homogenises undergraduates (Kelly, 2015) and exaggerates their individual agency (National Audit Office, 2017). Attempts to mesh VfM with market features such as 'choice' and 'accountability' (Higher Education and Research Act, 2017) had little resonance in our data. Institutional choice was often constrained by geography, and institutional accountability was limited in the short term. ${ }^{19}$ Far from a 'mirage' (Hayek, 1973), social justice was implied by students to be tangible and important, with many indicating that the funding model was inequitable on multiple levels. The 'return on investment' rhetoric, as introduced by Lord Dearing (1997) and amplified in policy discourse since, was internalised

${ }^{19}$ This is because "students can do little to influence quality once on a course ... [and] are unable to drive quality through switching providers' (National Audit Office, 2017, p. 9). 
by a minority of interviewees only, typically by those with a history of paid-for education. For most students, VfM was dismissed as immeasurable at the point of participation, as perhaps captured most succinctly by the student who responded 'I don't know what life will be like'.

When asked to assess VfM in binary terms, outcomes from this study mirror those of Student Academic Experience Surveys (Neves \& Hillman 2016, 2017 and 2018). However, our more in-depth methods demonstrate that students can express high levels of satisfaction with their course but remain firmly VfM negative if they believe it to be overpriced. This raises questions about the claim that 'quality of teaching, fair assessment and helpful feedback and learning resources are the factors which most demonstrate value for money for students' (Higher Education and Research Act, 2017). ${ }^{20}$ We find something quite different: that the perceived cost of participation affects students' assessment of VfM more than the perceived quality of the university's provision. With quantitative evidence (e.g. Institute for Fiscal Studies, 2018) shaping VfM discourses more than qualitative approaches, the 'cost sharing' load (Johnstone, 2004) is assumed to fall most defensibly on the individually graduate. However, the capitals exchanged in the higher education field differ so markedly according to students' background characteristics (Reay et al., 2005) that outcome-based analyses of VfM which presupposes a homogenised student body are likely to be incomplete or misleading. ${ }^{21}$

Indeed, a key contribution of this research is to show that VfM itself may be a social class-related construct. Cook, Watson, and Webb (2018) suggest that working class young people are more likely to focus on the financial benefits of participation, while their middle class peers see their degree as 'just one piece of the jigsaw in 'positioning' themselves to gain an advantageous outcome regarding employment, remuneration and better life outcomes in

\footnotetext{
${ }^{20}$ OfS research drew similar conclusions, noting that 'quality of teaching' was the main factor that influenced VfM, with $94 \%$ of students regarding this as 'very important' (2018b, p. 16).

${ }^{21}$ Our qualitative data reflects quantitative differences by school type identified in larger surveys, such as the OfS's finding that ' $58 \%$ of those that attended a private school believe that their overall investment in higher education has been good value for money, compared to only $50 \%$ of those that attended a state school.' (2018b, p. 12).
} 
general' (2018, p. 10). We find similar patterns emerging when students talk about VfM. Though our methods are limited because we use students' WP status - as determined independently and according to different criteria by our two host universities - as a proxy for social class, we flag these patterns as an important issue in need of further investigation. If VfM is indeed assessed differently by students of different socio-economic backgrounds then its centrality to university regulation (Higher Education and Research Act, 2017; OfS, 2018a) and policy discourse (Johnson, 2017; Gyimah, 2018) requires reconsideration.

More optimistically, our data include 'glimpses' of transformation and renewal noted by Ranson (2003). Even with no robust counter-narrative emerging from the sector about the longer term value of higher education, we found young people attempting to visualise university through a non-economistic lens and talk about their participation in nonfinancialised language, much like those canvassed by Tomlinson (2017) who explicitly rebuffed their student-consumer positioning. The notion of public value (Moore, 1995) persists, and the multiple 'publics' (Benington, 2009) created by higher education policy include students that invert dominant discourses by seeking alternative, non-monetary 'returns' on their 'investment'. 


\section{References}

Bachan, R. (2014). Students' expectations of debt in UK higher education. Studies in Higher Education, 39(5), 848-873.

Ball, S.J. (2017). The Education Debate. London: Policy Press.

Barnett, R. (1990). The Idea of Higher Education. London: McGraw-Hill Education UK.

Bates, E.A., \& Kaye, L.K. (2014). 'I'd be expecting caviar in lectures': the impact of the new fee regime on undergraduate students' expectations of higher education. Higher Education, 67(5), 655-673.

Benington, J. (2009). Creating the public in order to create public value? International Journal of Public Administration 32(3-4), 232-249.

Bourdieu, P. (2000). Pascalian Meditations. Cambridge: Polity Press.

Brown, R., \& Carasso, H. (2013). Everything for sale?: the marketisation of UK higher education. London: Routledge.

Budd, R. (2017). Undergraduate orientations towards higher education in Germany and England: problematizing the notion of 'student as customer'. Higher Education, 73(1), 2337.

Callender, C., \& Jackson, J. (2008). Does the fear of debt constrain choice of university and subject of study? Studies in Higher Education, 33(4), 405-429.

Callender, C., \& Mason, G. (2017). Does student loan debt deter higher education participation? New evidence from England. The ANNALS of the American Academy of Political and Social Science, 671(1), 20-48.

Collini, S. (2011). From Robbins to McKinsey. London Review of Books, 33(16), 9-14.

Collini, S. (2016). Who are the Spongers Now? London Review of Books, 38(2), 33-37.

Cook, S., Watson, D., \& Webb, R. (2018). 'It's just not worth a damn!' Investigating perceptions of the value in attending university. Studies in Higher Education, 44(7), 12561267.

Dearing, R.E. (1997). The Dearing Report. The National Committee of Enquiry into Higher Education. Retrieved from

http://www.educationengland.org.uk/documents/dearing1997/dearing1997.html\#22

Department for Business, Innovation and Skills. (2011). Higher Education: Students at the heart of the system. The Stationery Office Limited on behalf of the Controller of Her Majesty's Stationery Office. Retrieved from https://www.gov.uk/government/consultations/higher-education-white-paper-students-atthe-heart-of-the-system

Formby, A.P. (2017). 'Got a degree...: The role of 'stigma' in 'precarious' graduate transitions. Journal of Poverty and Social Justice, 25(3), 249-262.

Gyimah, S. (2018). Delivering Value for Money in the Age of the Student. Retrieved from. https://www.gov.uk/government/speeches/delivering-value-for-money-in-the-age-of-thestudent

Harris, D., Black, L., Hernandez-Martinez, P., Pepin, B., Williams, J., \& with the TransMaths Team. (2015). Mathematics and its value for engineering students: what are the implications for teaching? International Journal of Mathematical Education in Science and Technology, 46(3), 321-336. 
Harrison, N., Chudry, F., Waller, R., \& Hatt, S. (2015). Towards a typology of debt attitudes among contemporary young UK undergraduates. Journal of Further and Higher Education 39(1), 85-107.

Harrison, N., \& McCaig, C. (2017). Examining the epistemology of impact and success of educational interventions using a reflective case study of university bursaries. British Educational Research Journal, 43(2), 290-309.

Hayek, F.A. (1945). The Use of Knowledge in Society. The American Economic Review, 35(4), 519-530. Retrieved from https://www.jstor.org/stable/1809376?seq=1\#page_scan_tab_contents

Hayek, F.A. (1973). Law, Legislation and Liberty: A New Statement of the Liberal Principles of Justice and Political Economy Volume I: Rules and Order. Chicago: University of Chicago Press.

Higher Education and Research Act (2017). Retrieved from http://www.legislation.gov.uk/ukpga/2017/29/contents/enacted

Hillman, N. (2016). The Coalition's higher education reforms in England, Oxford Review of Education, 42(3), 330-345.

Institute for Fiscal Studies (2018). The impact of undergraduate degrees on early-career earnings. Research report: November 2018. Retrieved from:

https://dera.ioe.ac.uk/33021/1/The_impact_of_undergraduate_degrees_on_earlycareer_earnings.pdf

Johnson, J. (2015). Fulfilling our potential: Teaching Excellence, Social Mobility and Student Choice. Cm9141. London: Williams Lea Group on behalf of the Controller of Her Majesty's Stationery Office. Retrieved from https://www.gov.uk/government/consultations/higher-education-teaching-excellencesocial-mobility-and-student-choice

Johnson, J. (2016). Success as a knowledge economy: Teaching excellence, social mobility and student choice. London: Williams Lea Group on behalf of the Controller of Her Majesty's Stationery Office. Retrieved from https://www.gov.uk/government/publications/higher-education-success-as-a-knowledgeeconomy-white-paper

Johnson, J. (2017). Delivering value for money for students and taxpayers. Retrieved from https://www.gov.uk/government/speeches/jo-johnson-delivering-value-for-money-forstudents-and-taxpayers

Johnstone, D. B. (2004). The economics and politics of cost sharing in higher education: comparative perspectives. Economics of Education Review, 23(4), 403-410.

Jones, S. (2016). Expressions of student debt aversion and tolerance among academically able young people in low-participation English schools. British Educational Research Journal, 42(2), 277-293.

Jones, S., Sutcliffe, M.J., Bragg, J., \& Harris, D. (2016). To what extent is capital expenditure in UK Higher Education meeting the pedagogical needs of staff and students? Journal of Higher Education Policy and Management, 38(4), 477-489.

Kelly, P. (2015). Growing up after the GFC: Responsibilisation and mortgaged futures. Discourse: Studies in the Cultural Politics of Education 38(1), 57-69. 
McCowan, T. (2017). Higher education, unbundling, and the end of the university as we know it. Oxford Review of Education, 43(6), 733-748.

McGettigan, A. (2013). The Great University Gamble: Money, markets and the future of higher education. London: Pluto Press.

McGuigan, M., McNally, S., \& Wyness, G. (2016). Student awareness of costs and benefits of educational decisions: effects of an information campaign. Journal of Human Capital, $10(4), 482-519$.

Moore, M.H. (1995). Creating public value: Strategic management in government. Harvard: Harvard University Press.

National Audit Office (2018). The Higher Education Market. Department for Education. Retrieved from https://www.nao.org.uk/report/the-higher-education-market/

Naidoo, R. (2004). Fields and institutional strategy: Bourdieu on the relationship between higher education, inequality and society. British Journal of Sociology of Education, 25(4), 457-471.

Neves, J., \& Hillman, N. (2016). Student Academic Experience Survey. Higher Education Policy Institute and Higher Education Academy. Retrieved from http://www.hepi.ac.uk/2016/06/09/hepi-hea-2016-student-academic-experience-survey/

Neves, J., \& Hillman, N. (2017). Student Academic Experience Survey. Higher Education Policy Institute and Higher Education Academy. Retrieved from http://www.hepi.ac.uk/2017/06/07/2017-student-academic-experience-survey/

Neves, J., \& Hillman, N. 2018. Student Academic Experience Survey. Higher Education Policy Institute and Higher Education Academy. Retrieved from http://www.hepi.ac.uk/2018/06/07/turning-corner-value-money-2018-hepi-advancestudent-academic-experience-survey-highlights-students-belief-value-money-highereducation-improving/

Nixon, J. (2010). Higher Education and the Public Good: Imagining the university. London: Bloomsbury.

Office for Students (2018a). What is value for money for students? Retrieved from https://www.officeforstudents.org.uk/advice-and-guidance/regulation/value-for-money/

Office for Students (2018b). Value for money: the student perspective. Retrieved from Trendence UK. https://studentsunionresearch.com/

Public Accounts Committee (2018). The Higher Education Market. Retrieved from https://www.parliament.uk/business/committees/committees-a-z/commons-select/publicaccounts-committee/inquiries/parliament-2017/higher-education-market-1719/publications/

Raaper, R. (2018). Students' Unions and Consumerist Policy Discourses in English higher education. Critical Studies in Education, 1-17. doi: 10.1080/17508487.2017.1417877

Ranson, S. (2003). Public accountability in the age of neo-liberal governance. Journal of Education Policy, 18(5), 459-480.

Reay, D., Crozier, G., \& Clayton, J. (2010). 'Fitting in' or 'standing out': Working class students in UK higher education. British Educational Research Journal, 36(1), 107-124.

Reay, D., David, M.E., \& Ball, S.J. (2005). Degrees of choice: Class, race, gender and higher education. London: Trentham Books. 
Robbins, L. (1963). Higher Education: Report of the Committee appointed by the Prime Minister under the chairmanship of Lord Robbins, 1961-63. No. 2. HM Stationery Office. Retrieved from http://www.educationengland.org.uk/documents/robbins/robbins1963.html Smyth, J. (2017). The Toxic University: Zombie leadership, academic rock stars and neoliberal ideology. New York: Springer.

Talbot, C. (2011). Paradoxes and prospects of 'public value'. Public Money and Management, 31(1), 27-34.

Temple, P., Callender, C., Grove, L., \& Kersh, N. (2014). Managing the student experience in a shifting higher education landscape. York: The Higher Education Academy. Retrieved from https://www.heacademy.ac.uk/sites/default/files/resources/managing_the_student_experie nce.pdf

Tomlinson, M. (2017). Student perceptions of themselves as 'consumers' of higher education. British Journal of Sociology of Education, 38(4), 450-467.

Vigurs, K., Jones, S., \& Harris, D. (2016). Greater expectations of graduate futures? A comparative analysis of the views of the last generation of lower-fees undergraduates and the first generation of higher-fees undergraduates at two English universities. London: SRHE. Retrieved from https://www.srhe.ac.uk/downloads/vigurs-katy.pdf

Vigurs, K., Jones, S., Everitt, J., \& Harris, D. (2018a). Higher fees, higher debts: Unequal graduate transitions in England? In Sheila Riddell, Sarah Minty, Elizabet Weedon, \& Susan Whittaker (Eds) Higher Education Funding and Access in International Perspective, Bingley: Emerald, pp. 81-98.

Vigurs, K., Jones, S., Everitt, J., \& Harris, D. (2018b). Re-imagining the Gap Year in a Climate of Higher University Fees and Student Debt. In Ciaran Burke and Fiona Christie (Eds) Graduate Careers in Context: Research, Policy and Practice, Abingdon: Routledge.

Wilkins, S., Shams, F., \& Huisman, J. (2013). The decision-making and changing behavioural dynamics of potential higher education students: the impacts of increasing tuition fees in England. Educational Studies, 39(2), 125-141.

Willetts, D. (2011). Statement on higher education funding and student finance. Retrieved from https://www.gov.uk/government/speeches/statement-on-higher-education-fundingand-student-finance--2

Woodall, T., Hiller, A., \& Resnick, S. (2014). Making sense of higher education: students as consumers and the value of the university experience. Studies in Higher Education 39(1), 48-67.

Which? (2014). A degree of value: Value for money from the student perspective. Retrieved from https://www.which.co.uk/policy/public-services/370/a-degree-of-value-value-formoney-from-the-student-perspective-which-report 